\title{
Respiratory dependence of the CCCP-resistant luminescence of Vibrio harveyi
}

\author{
Minoru Wada, ${ }^{*}$ Kazuhiro Kogure, Kouichi Ohwada and Usio Simidu $\dagger$ \\ Ocean Research Institute, University of Tokyo, 1-15-1 Minamidai, Nakano-ku, Tokyo 164, Japan
}

(Received 15 June 1992; revised 31 August 1992; accepted 4 September 1992)

\begin{abstract}
The relation between respiration and luminescence of Vibrio harveyi was studied in the presence of the proton conductor CCCP (carbonyl cyanide $m$-chlorophenylhydrazone). CCCP affected both luminescence and oxygen uptake rate, but did not alter the cellular ATP level. In the absence of CCCP, luminescence and oxygen uptake rate were almost constant over the $\mathrm{pH}$ range 6.5-8.5. However, at $10 \mu \mathrm{M}$-CCCP, both were apparently pH-dependent, with maxima observed at $\mathrm{pH} 8.5$ and minima at $\mathrm{pH}$ 6.5. In the presence of $\mathrm{CCCP}(0 \cdot 1-10 \mu \mathrm{M})$, the changes in the luminescence were in close correlation with those in the oxygen uptake rate regardless of the pH. HQNO (2heptyl-4-hydroxyquinoline- $\mathrm{N}$-oxide) and $\mathrm{NaCN}$ inhibited the CCCP-resistant luminescence. From these results, it is concluded that the CCCP-resistant luminescence is respiratory-dependent.
\end{abstract}

\section{Introduction}

In marine luminous bacteria, the relation between luminescence and the respiratory system has been extensively documented. Since the luciferase system can be viewed as an alternative electron transport pathway, competition between the two systems has been recognized, (Grogan, 1984; Hastings \& Nealson, 1977; Nealson et al., 1970; Ulitzur et al., 1981; Watanabe et al., 1975).

Carbonyl cyanide $m$-chlorophenylhydrazone (CCCP), a proton-conducting uncoupler, has been used to study the luminescent pathway (Grogan, 1984; Guerrero \& Makemson, 1989). CCCP is generally thought to increase proton permeability across the cell membrane, with consequent dissipation of the membrane potential and inhibition of ATP synthesis. Thus growth and the various cellular processes which depend on the protonmotive force are strongly inhibited in the presence of CCCP.

\footnotetext{
* Author for correspondence. Tel. (03) 3376 1251; fax (03) 33756716.

$\dagger$ Present address: Faculty of Applied Biological Science, Hiroshima University, Higashihiroshima 724, Hiroshima, Japan.
}

Abbreviations: CCCP, carbonyl cyanide $m$-chlorophenylhydrazone; HQNO, 2-heptyl-4-hydroxyquinoline- $N$-oxide.
However, in our previous study, we found that Vibrio harveyi showed CCCP-resistant growth and luminscence at $\mathrm{pH} 8.5$, but not at $\mathrm{pH} 6.5$ (Wada et al., 1992). A similar growth pattern has been found in other marine bacteria which possess a distinct respiratory chain involving a primary $\mathrm{Na}^{+}$pump (Tokuda \& Unemoto, 1983; Kogure $\&$ Tokuda, 1986). This pump translocates sodium ions from the inside to the outside of the cells at alkaline $\mathrm{pH}$, as a result of electron transport. This suggested a close coupling between the luminescent system and the $\mathrm{Na}^{+}$ driven respiratory chain in $V$. harveyi at alkaline $\mathrm{pH}$.

In this report we describe a close correlation between luminescence and respiratory activity in $V$. harveyi in the presence of CCCP.

\section{Methods}

Bacterial strain and preparation of cell suspension. Vibrio harveyi ATCC 14126 was incubated in PYG medium (pH 7.5) at $20^{\circ} \mathrm{C}$ as described previously (Wada et al., 1992). When $\mathrm{OD}_{600}$ reached about 1.0 , cells were harvested by centrifugation $\left(10000\right.$ r.p.m., $\left.1 \mathrm{~min}, 4^{\circ} \mathrm{C}\right)$ After washing twice with $25 \mathrm{~mm}$-Tris buffer containing $30 \mathrm{mM}$ $\mathrm{MgSO}_{4} .7 \mathrm{H}_{2} \mathrm{O}, 10 \mathrm{~mm}-\mathrm{KCl}$ and $0.3 \mathrm{M}-\mathrm{NaCl}$, cells were resuspended in the same buffer. The $\mathrm{pH}(6 \cdot 5-8 \cdot 5)$ was adjusted with $\mathrm{HCl}$. The cell suspension contained about $0.4 \mathrm{mg}$ protein per $\mathrm{ml}$, unless otherwise noted. When the effect of $n$-decanal on luminescence was studied, the suspension was diluted 10 times with the buffer. The suspension was kept on ice until use. 
Measurement of luminescence. Luminescence of the cell suspension was monitored with an ATP photometer (SAI Technology, Model 3000). Cell suspension $(1 \mathrm{ml})$ was put in a glass vial and kept at $25^{\circ} \mathrm{C}$. After $5 \mathrm{~min}$, luminscence was measured for $6 \mathrm{~s}$ and the peak value was monitored. Light intensity was expressed in count units of the photometer per $\mathrm{mg}$ cell protein.

Measurement of oxygen uptake rate. The oxygen consumption rate of the cell suspension was determined at $25^{\circ} \mathrm{C}$ with an oxygen electrode (Rank). Measurement was started by the addition of $20 \mu \mathrm{l}$ cell suspension to $2 \mathrm{ml}$ of air-saturated buffer. The final cell concentration was the same as that for luminescent determination.

Measurement of ATP content. ATP was extracted from cells by the method of Goulbourne \& Greenberg (1980). The cell suspension $(0 \cdot 2$ $\mathrm{ml}$ ) was mixed with $2 \mathrm{ml}$ boiling Tris buffer $\left(20 \mathrm{mM}\right.$, pH 7.5 at $\left.25^{\circ} \mathrm{C}\right)$. After $10 \mathrm{~min}$, samples were stored at $-20^{\circ} \mathrm{C}$ for later analysis. ATP content was measured by firefly luciferase-luciferin (Sigma).

Chemicals. CCCP and 2-heptyl-4-hydroxyquinoline- $N$-oxide (HQNO) were purchased from Sigma. $n$-Decanal was obtained from Nakarai Tesque (Kyoto, Japan). CCCP and $n$-decanal were dissolved in dimethyl sulphoxide (DMSO). HQNO was dissolved in methanol. In cell suspensions containing these chemicals, DMSO or methanol concentrations did not exceed $1 \%(\mathrm{v} / \mathrm{v})$. This concentration of solvent did not affect luminescence or the oxygen uptake rate of $V$. harveyi. $\mathrm{NaCN}$ or $\mathrm{KCN}$ was added to the suspensions as aqueous solution.

\section{Results}

Effects of the proton-conductor $\mathrm{CCCP}$ on the luminescence of $V$. harveyi were determined at $\mathrm{pH} 6.5$ and 8.5 . Luminescence at $\mathrm{pH} 6.5$ was immediately and almost completely inhibited by the addition of $1 \mu \mathrm{M}$-CCCP (Fig. 1 a), but at $\mathrm{pH} 8 \cdot 5$, considerable luminescence was observed even in the presence of $100 \mu \mathrm{M}$-CCCP (Fig. $1 b$ ).

Luminescence and respiratory activity were determined at $\mathrm{pH} 6.5$ and 8.5 as a function of CCCP concentration (Fig. 2). Oxygen uptake rate at $\mathrm{pH} 6.5$ was slightly enhanced at $0 \cdot 1 \mu \mathrm{M}-\mathrm{CCCP}$, but markedly reduced at more than $1 \mu \mathrm{M}$. At $\mathrm{pH} 8 \cdot 5$, however, oxygen uptake was stimulated throughout the concentration range $(0 \cdot 1-10 \mu \mathrm{M})$ tested. Although changes in the luminescence and the oxygen uptake rate with respect to the CCCP concentration were more significant at $\mathrm{pH} 6.5$ than at 8.5 , the changes in luminescence and oxygen uptake closely paralleled each other. This correlation implied a respiratory-dependence of the luminescence in the presence of CCCP.

The effects of $\mathrm{pH}$ on the CCCP-resistant luminescence and the oxygen uptake rate are shown in Fig. 3. In the absence of CCCP, the luminescence is almost constant over the $\mathrm{pH}$ range tested $(6 \cdot 5-8 \cdot 5)$. However, in the presence of $10 \mu \mathrm{M}-\mathrm{CCCP}$, the luminescence became $\mathrm{pH}$ dependent, with the maximum luminescence at $\mathrm{pH} 8.5$ and the minimum at $\mathrm{pH} 6.5$. The response of the oxygen

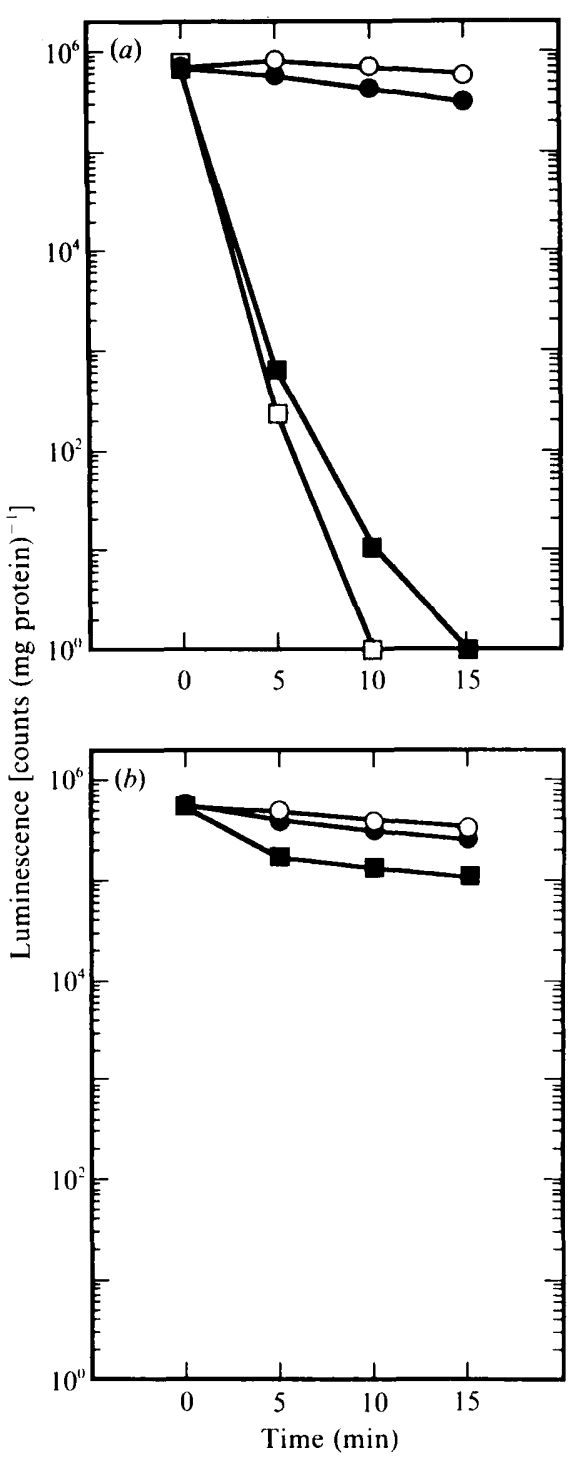

Fig. 1. Effects of CCCP on the luminescence of $V$. harveyi at $(a) \mathrm{pH} 6.5$ and $(b) \mathrm{pH} \mathrm{8.5.} \mathrm{After} \mathrm{determination} \mathrm{of} \mathrm{luminescence} \mathrm{at} \mathrm{zero} \mathrm{time,}$ CCCP was added to the suspension. (a) $O, 0 ; \bullet, 0 \cdot 1 ; \boldsymbol{\square}, 1 \cdot 0 ; \square, 10 \mu \mathrm{M}$ CCCP (final concentrations). (b) $\bigcirc, 0 ; \bullet, 1 \cdot 0 ; \mathbf{\square}, 100 \mu \mathrm{M}-\mathrm{CCCP}$ (final concentrations).

uptake rate to the external $\mathrm{pH}$ in the presence and absence of CCCP gave a profile similar to the luminescence data (Fig. 3).

To ensure that the CCCP-resistant luminescence was respiratory-dependent, cells were treated with respiratory inhibitors. Luminescence in the presence of $10 \mu \mathrm{M}$ $\mathrm{CCCP}$ at $\mathrm{pH} 8.5$ was inhibited by $2 \mathrm{mM}-\mathrm{NaCN}$ and 100 $\mu \mathrm{M}-\mathrm{HQNO}$ (Fig. 4). Under these conditions, the oxygen uptake rates with $\mathrm{CCCP}$, with $\mathrm{CCCP}+\mathrm{NaCN}$ and with CCCP + HQNO were $96.0 \pm 7 \cdot 6,18.4 \pm 1.0$ and $23 \cdot 7 \pm 2 \cdot 2 \mathrm{nmol}$ oxygen $\mathrm{min}^{-1}$ (mg protein) ${ }^{-1}$, respec- 


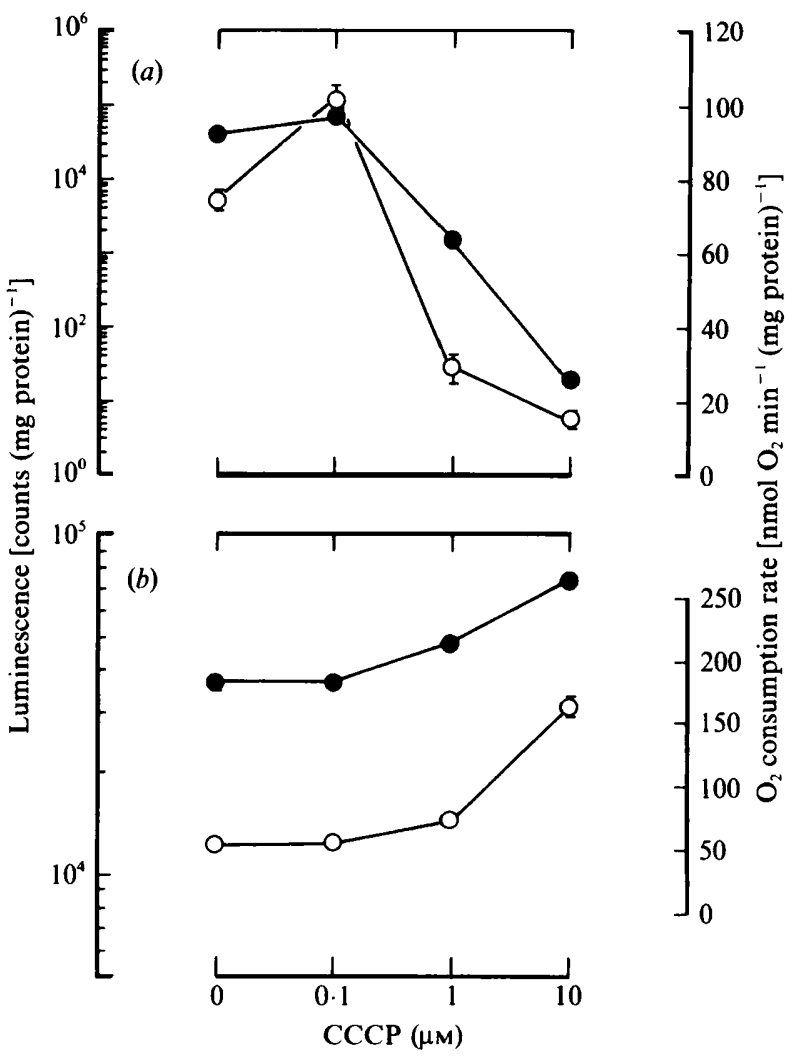

Fig. 2. Effects of CCCP on the luminescence and oxygen uptake rate of $V$. harveyi at $(a) \mathrm{pH} 6.5$ and $(b) \mathrm{pH} 8.5$. Luminescence $(\bullet)$ and oxygen uptake rate $(O)$ were determined $5 \mathrm{~min}$ after CCCP addition. Bars represent errors of the duplicate assay.

tively. These results indicate that the CCCP-resistant luminescence at $\mathrm{pH} 8.5$ was respiratory-dependent. It seems most likely that inhibitor blocking of electron flow through the respiratory chain and a resultant inhibition of functioning of the $\mathrm{Na}^{+}$pump lead to a decrease in the electron flow rate through the luminescent system in the presence of CCCP (see Discussion).

Since aldehyde synthesis from fatty acids requires both NADPH and ATP, this reaction can be a limiting step in bacterial luminescent systems. Addition of an aldehyde (tetradecanal) causes a stimulation of in vivo luminescence, both in the absence and the presence of respiratory inhibitors (Grogan, 1984; Guerrero \& Makemson, 1989; Makemson, 1986), and had a similar effect on luminescence in the presence of CCCP in this study. Inhibition of luminescence caused by $10 \mu \mathrm{M}-$ CCCP at $\mathrm{pH} 6.5$ and that of CCCP-resistant luminescence by $2 \mathrm{mM}-\mathrm{KCN}$ at $\mathrm{pH} 8.5$ could be partly restored by $50 \mu \mathrm{M}$-decanal (Fig. 5). However, neither CCCP nor KCN affected intracellular ATP levels (Table 1). Thus, a decrease in the cellular ATP pool does not seem to be a
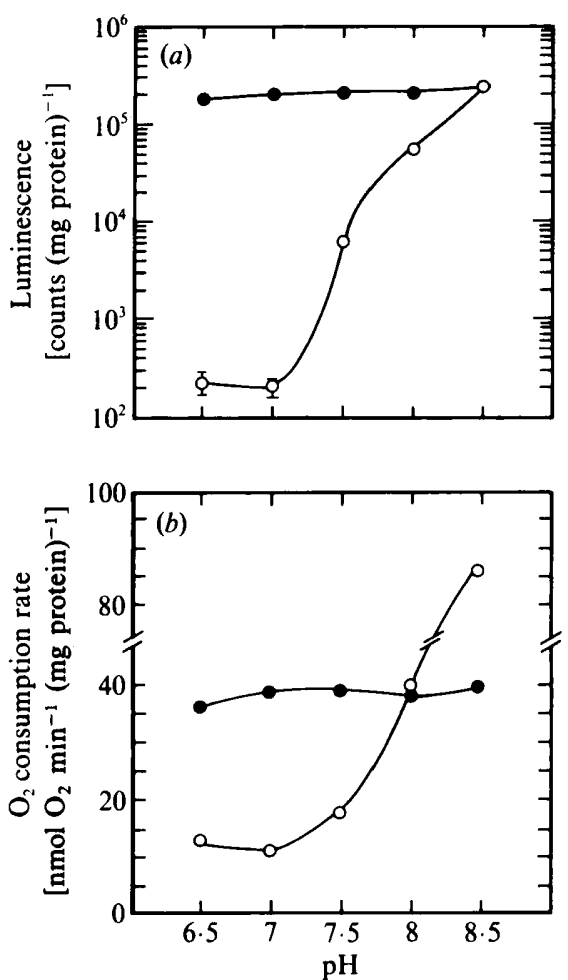

Fig. 3. Effects of $\mathrm{pH}$ on the luminescence ( $a$ ) and oxygen consumption (b) of $V$. harveyi in the presence of CCCP. CCCP was added to a final concentration of $10 \mu \mathrm{M}(O)$. DMSO was used as a control $(\bullet)$. Luminescence was determined $5 \mathrm{~min}$ after CCCP or DMSO addition. Bars represent errors of the duplicate assay.

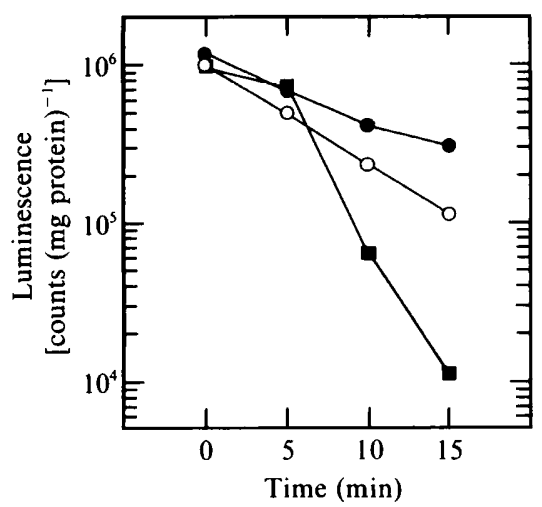

Fig. 4. Inhibition of the CCCP-resistant luminescence of $V$. harveyi by respiratory inhibitors at $\mathrm{pH} 8.5$. CCCP was added to give a final concentration of $10 \mu \mathrm{M}$. Just after the determination of the luminescence at zero time, $\mathrm{NaCN}$ and $\mathrm{HQNO}$ were added to the suspension to give final concentrations of $2 \mathrm{mM}$ and $100 \mu \mathrm{M}$, respectively. $\bullet$, CCCP; $\mathrm{O}, \mathrm{CCCP}+\mathrm{HQNO} ; \mathbf{\square C C P}+\mathrm{NaCN}$. Data represent mean values of duplicate assay (deviations are too small to show in this figure).

cause of the inhibition of luminescence, although deficiency in a long-chain aldehyde may be partly involved. 
(a)
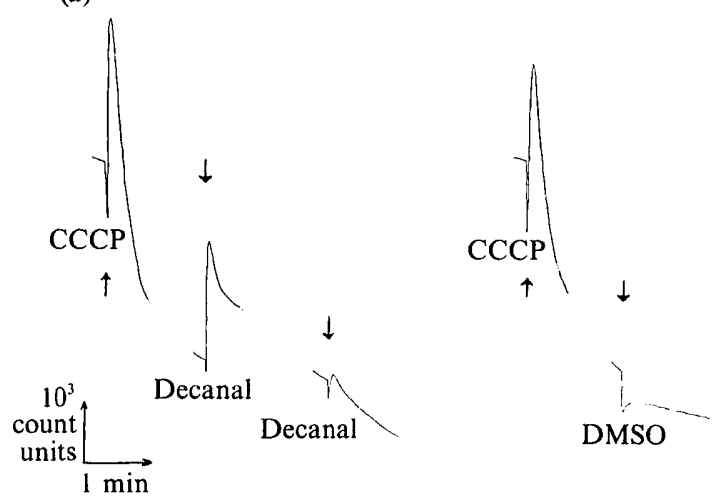

(b)
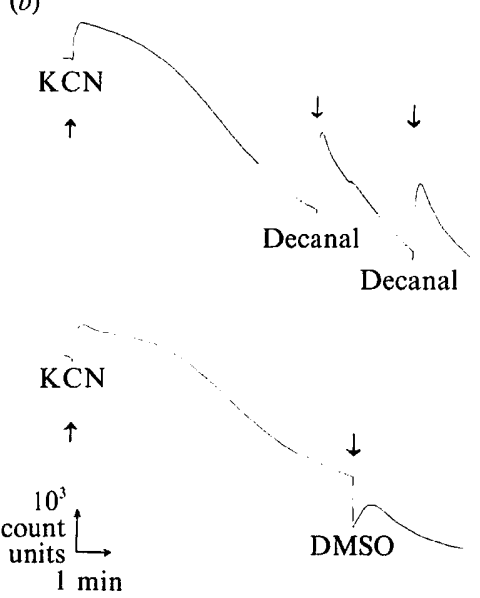

Fig. 5. Effect of decanal addition on the luminescence of $V$. harveyi in the presence of $10 \mu \mathrm{M}-\mathrm{CCCP}$ at $(a) \mathrm{pH} 6.5$ and $(b) \mathrm{pH} 8.5$. The cell suspension contained about $0.04 \mathrm{mg}$ protein $\mathrm{ml}^{-1}$. Decanal was added to a final concentration of $100 \mu \mathrm{M}$. $\mathrm{KCN}$ was added to a final concentration of $2 \mathrm{~mm}$. Each arrow represents the addition of the reagent. DMSO was added to $1 \%(\mathrm{v} / \mathrm{v})$ as a control for decanal addition.

Table 1. ATP content of $V$. harveyi in the presence of CCCP

Cellular ATP levels were determined 5 min after CCCP addition at $\mathrm{pH} 6.5$ and $8 \mathrm{~min}$ after $\mathrm{CCCP}$ addition at $\mathrm{pH} 8.5$. Data are means from a duplicate assay.

\begin{tabular}{|c|c|c|}
\hline $\mathrm{pH}$ & & $\begin{array}{c}\text { ATP content } \\
{\left[\mu \mathrm{g} \text { ATP }(\mathrm{mg} \text { cell protein })^{-1}\right]}\end{array}$ \\
\hline 6.5 & $\begin{array}{l}\text { DMSO } \\
10 \mu \mathrm{M}-\mathrm{CCCP}\end{array}$ & $\begin{array}{l}1 \cdot 10 \pm 0 \cdot 10 \\
1 \cdot 22 \pm 0 \cdot 12\end{array}$ \\
\hline $8 \cdot 5$ & $\begin{array}{l}10 \mu \mathrm{M}-\mathrm{CCCP} \\
10 \mu \mathrm{M}-\mathrm{CCCP}+2 \mathrm{mM}-\mathrm{KCN}\end{array}$ & $\begin{array}{l}0.40 \pm 0.08 \\
0.58 \pm 0.03\end{array}$ \\
\hline
\end{tabular}

\section{Discussion}

Both the luminescence and the oxygen uptake rate of $V$. harveyi were sensitive to the proton-conductor CCCP. These processes were more resistant to $\mathrm{CCCP}$ at alkaline than at acidic pHs (Fig. 2 and 3). Although Guerrero \& Makemson (1989) reported only the inhibitory effects of CCCP on bacterial luminescence and respiration, our results show more detailed responses of these processes to CCCP in $V$. harveyi. Stimulation of both luminescence and oxygen uptake by CCCP was observed at $\mathrm{pH} 6.5$ and 8.5 , although the range of CCCP concentration was different (Fig. 2); less than $0.1 \mu \mathrm{M}$ at $\mathrm{pH} 6.5$, and more than $0.1 \mu \mathrm{M}$ at $\mathrm{pH} 8.5$.

As CCCP increases proton permeability across the cell membrane, the following changes will generally occur: changes in the cytoplasmic cation environment, dissipation of membrane potential and a consequent increase in respiration. If the perturbation of the cytoplasmic cation environment by CCCP is extensive, respiration and any other cellular metabolism will cease. In fact, Tokuda \& Unemoto (1983) showed that, at pH 6.5, CCCP caused leakage of $\mathrm{K}^{+}$and inhibition of growth in Vibrio alginolyticus. However, at $\mathrm{pH} 8 \cdot 5$, the cytoplasmic cation environment was almost conserved and substantial growth was observed even in the presence of CCCP. These results can be explained by a switching of respiratory chain system from $\mathrm{H}^{+}$-dependence $\left(\mathrm{H}^{+}\right.$ pump) to $\mathrm{Na}^{+}$-dependence $\left(\mathrm{Na}^{+}\right.$pump) (Tokuda \& Unemoto, 1983).

Our previous study (Wada et al., 1992) found that $V$. harveyi possessed a $\mathrm{Na}^{+}$-dependent $\mathrm{NADH}$ oxidase, and was able to grow in the presence of CCCP at $\mathrm{pH} 8.5$, but not at $\mathrm{pH} 6.5$. From these results, $V$. harveyi was considered to possess a respiratory-dependent primary $\mathrm{Na}^{+}$pump similar to that of $V$. alginolyticus. Although cytoplasmic cation environments were not checked, the responses to CCCP in $V$. harveyi presented in this report would be explained by analogy as follows: at acidic $\mathrm{pH}$, maintenance of the cytoplasmic cation environment depends on $\mathrm{H}^{+}$circulation driven by $\mathrm{H}^{+}$pumps, and addition of CCCP would result in severe perturbation of cytoplasmic $\mathrm{pH}$ and the cation environment. On the other hand, under alkaline conditions, when the $\mathrm{Na}^{+}$ pump is functional, $V$. harveyi is able to maintain a normal cytoplasmic cation environment even in the presence of CCCP. Thus, normal cellular works including light production proceed at $\mathrm{pH} 8.5$. In other words, high sensitivity at acidic $\mathrm{pH}$ and insensitivity at alkaline pH to CCCP would be attributed to the $\mathrm{H}^{+}$and $\mathrm{Na}^{+}$ pumps, respectively.

The inhibition of bacterial luminescence by $\mathrm{CCCP}$ has been considered a consequence of a decrease in intracellular ATP, which is required for aldehyde recycling (Guerrero \& Makemson, 1989). Restoration of the CCCP-induced inhibition by $n$-decanal shown in Fig. 5 seems to be consistent with this idea. However we observed that CCCP had no apparent effect on intracellular ATP level (Table 1). Thus, although lack of 
aldehyde itself may be partly involved in the inhibition, it seems unlikely that the energy from ATP hydrolysis is directly coupled to the luminescence.

It is more reasonable to explain the results in the context of the respiratory electron transport activity or the rate of electron flow. The close correlation between luminescence and oxygen uptake rate (Fig. 2) strongly supports this idea. The oxygen uptake rate corresponds closely to the respiratory electron transport activity, indicating that the luminescence is linked to or depends on the respiratory electron transfer. This linkage was further supported by the inhibition of CCCP-resistant luminescence by $\mathrm{NaCN}$ and HQNO (Fig. 4). As stated above, in the presence of CCCP at pH 8.5, maintenance of the cellular cation environment is presumed to be fastidious and strictly dependent on the $\mathrm{Na}^{+}$pump. Inhibition of the $\mathrm{Na}^{+}$pump by blocking electron flow through the respiratory chain system could result in a perturbation of the cellular ionic environment. This, in turn, would lead to a decrease in respiratory electron transport activity and hence the luminescence, although $\mathrm{NaCN}$ and HQNO both enhance luminescence in the absence of CCCP (data not shown).

We previously concluded (Wada et al., 1992) that luminescence was respiratory-dependent at $\mathrm{pH} 8.5$. In this study, we further observed that luminescence in the presence of CCCP was closely associated with respiratory activity over the $\mathrm{pH}$ range $6 \cdot 5-8 \cdot 5$.

We conclude that the luminescence of $V$. harveyi is respiratory-dependent in the presence of CCCP. This conclusion is consistent with our hypothesis that luminescence in $V$. harveyi primarily depends on the respiratory activity.
We wish to acknowledge Dr H. Tokuda, Institute of Applied Microbiology, University of Tokyo, for valuable discussions. We would like to thank Dr J. C. Makemson, Florida International University, for reviewing the manuscript.

\section{References}

Goulbourne, E. A. \& Greenberg, E. P. (1980). Relationship between protonmotive force and motility in Spirochaeta aurantia. Journal of Bacteriology 143, 1450-1457.

GroGaN, D. W. (1984). Interaction of respiration and luminescence in a common marine bacterium. Archives of Microbiology 137, 159-162.

Guerrero, M. A. \& Makemson, J. C. (1989). The cytochromes of luminous bacteria and their coupling to bioluminescence. Current Microbiology 18, 67-73.

Hastings, J. W. \& Nealson, K. H. (1977). Bacterial bioluminescence. Annual Review of Microbiology 31, 549-595.

Kogure, K. \& Tokuda, H. (1986). Membrane bioenergetics of halophilic marine bacteria. In Perspectives in Microbial Ecology: Proceedings of the Fourth International Symposium on Microbial Ecology, pp. 231-237. Ljubjana.

Makemson, J. C. (1986). Luciferase-dependent oxygen consumption by bioluminescent vibrios. Journal of Bacteriology 165, 461-466.

Nealson, K. H., Platt, T. \& Hastings, J. W. (1970). Cellular control of the synthesis and activity of the bacterial luminescent system. Journal of Bacteriology 104, 313-322.

TokudA, H. \& UNEMoto, T. (1983). Growth of a marine Vibrio alginolyticus and moderately halophilic $V$. costicola becomes uncoupler-resistant when the respiration-dependent $\mathrm{Na}^{+}$pump functions. Journal of Bacteriology 156, 636-643.

Ulitzur, S., Reinhertz, A. \& Hastings, J. W. (1981). Factors affecting the cellular expression of bacterial luciferase. Archives of Microbiology 137, 159-162.

Wada, M., Kogure, K., Ohwada, K. \& Simidu, U. (1992). Coupling between the respiratory chain and the luminescent system of Vibrio harveyi. Journal of General Microbiology 138, 1607-1611.

Watanabe, H., Mimura, N., Takimoto, A. \& Nakamura, T. (1975). Luminescence and respiratory activities of Photobacterium phosphoreum: competition for cellular reducing power. Journal of Biochemistry 77, $1147-1155$. 